\title{
KONDISI EKSTERNAL (PANJANG DAN BERAT TUBUH) DAN INTERNAL (Usus, POHON RESPIRASI DAN GONAD) TERIPANG GAMAT BATU Stichopus horrens SETELAH EVISERASI DAN PEMOTONGAN
}

\author{
Post Eviseration And Tranverse Fission Of External Condition (Body Length And Weight) And \\ Internal Condition (Intestines, Respiration Tree And Gonads) \\ Of Gamat Dragonfish Stichopus Horrens
}

Edwin Oscar Langi, Jetti Treslah Saselah

Teknologi Budidaya Ikan, Politeknik Negeri Nusa Utara, Email: edwinoscarlangi @gmail.com

\begin{abstract}
Abstrak: Mekanisme pertahanan diri organisme adalah salah satu upaya untuk hidup di habitatnya. Pada kelompok hewan berduri Echinodermata: dikenal dengan istilah autotomi, yaitu proses melepaskan organ tubuh secara spontan sebagai respons terhadap suatu rangsangan yang membuat biota tersebut stres. Biota ini mampu melakukan eviserasi, fission dan regenerasi setelah proses pemutusan. Produk akhirnya adalah organ internal dan individu baru. Penelitian ini dilakukan di Teluk Tahuna selama 28 hari. Hasilnya Teripang Gamat Batu Stichopus horrens yang eviserasi dan pemotongan melintang ternyata mengalami penyusutan ukuran yang cukup besar. Tidak ada spesimen yang bertambah ukurannya. Jika terjadi eviserasi bagian tubuh yang dibuang adalah isi perut, yaitu kotoran, dan sebagian usus. Bagian tubuh yang tersisa pada spesimen yang dipotong adalah yang melekat pada bagian anterior, yaitu pangkal tenggorokan, lambung dan sebagian usus. Sedangkan bagian posterior tidak pernah ditemukan gonad, hanya sebagian usus dan pohon respirasi yang berpangkal pada bagian kloaka. Kondisi organ internal (pencernaan, pohon respirasi dan gonad) setelah eviserasi maupun pemotongan melintang menyusut ukurannya, baik saat tebar awal sampai hari ke-28. Sehingga memberikan arti bahwa pada 4 minggu pertama individu teripang ini setelah belum melakukan regenerasi organ internal.
\end{abstract}

Kata kunci: Stichopus horrens, eviserasi, fission, gonad, pohon respirasi,

\begin{abstract}
The organism's self-defense mechanism is an attempt to live in its habitat. In the group of spiny animals Echinoderm: known as autotomy, which is the process of spontaneously releasing organs in response to a stimulus that stresses the biota. This biota is capable of evisceration, fission and regeneration after the transverse fission. The end products are internal organs and new individuals. This research was conducted in Tahuna Bay for 28 days. The result was that the sea cucumber Gama Batu or Stichopus horrens was revised and that the transverse fission actually experienced a significant reduction in size. There is no specimen that increased in size. If there is evisceration, the parts of the body that are removed are the stomach contents, namely feces, and part of the intestines. The body parts remaining in the transeverse fission specimen are those attached to the anterior, namely the larynx, stomach and a portion of the intestines. Parts of the body are missing. While the posterior gonads have never been found, only a part of the intestine and respiration tree originates from the cloaca. The condition of the internal organs (intestines, respiration tree and gonads) which were eviscerated and the transverse fission experienced a reduction in size, both during initial stocking until the 28th day. It means that in the first 4 weeks the individual these sea cucumber had not regenerated the internal organs.
\end{abstract}

Keywords: Stichopus horrens, evisceration, fission, intestines, gonad, respiration tree

\section{PENDAHULUAN}

Mekanisme pertahanan diri organisme adalah salah satu upaya untuk hidup di habitatnya. Pada kelompok hewan berduri Echinodermata dikenal dengan istilah autotomi, yaitu proses melepaskan organ tubuh secara spontan sebagai respons terhadap suatu 
rangsangan yang membuat biota tersebut stres. Pradina (1996) menyatakan bahwa biota ini mampu melakukan eviserasi, yaitu : mengeluarkan isi perut dan dengan cepat memulihkan organ tubuh yang hilang tersebut. Di samping itu teripang dapat memutuskan diri (fissiparous) dan memulihkan diri (regenerasi) kembali. Produk akhirnya adalah organ internal dan individu baru.

Jenis teripang yang dilaporkan memiliki kemampuan ini di antaranya adalah Cerah Hitam Holothuria atra di Samudera Pasifik (Conand, 1996) dan H. parvula di Samudera Atlantik (Emzon dan Mladenov, 1987 dalam Conand, 1996). Penelitian tentang reproduksi aseksual teripang di perairan wilayah Indonesia sudah ada, seperti pernah dilakukan oleh Hermawan $d k k$. (2012) di Perairan Pulau Karimun Jawa dengan jenis Gamat Stichopus horrens dan S. vastus. Saputra (2016) di perairan Rajaampat, Papua dengan jenis Cerah Hitam H. atra. Di kawasan perairan Sangihe sudah ada laporan dari penelitian sebelumnya tentang 8 jenis teripang yang memilili kemampuan reproduksi aseksual dengan cara diikat dan dipotong, yaitu Gama Lumpur Stichopus. hermannii, Gamat Batu S. horrens, Cerah Merah Holothuria edulis, Cerah Hitam H. atra, $H$. arenicola dan Bintik Coklat Bohadschia marmorata, Bintik Polos B. vitiensis dan Bintik corak B. argus (Langi dan Wuaten, 2019).

Regenerasi organ internal setelah pemutusan telah dilaporkan oleh Dolmatov (2014) dari beberapa literatur mengenai tahap perubahannya pada 6 spesies teripang, yaitu Holothuria diffilicilis, H. parvula, H. atra, H. leucopolista, Stichopus chloronotus, dan Cladolabes schmeltzii. Hasil yang didapatnya adalah regenerasi organ internal teripang kelompok holothurians setelah pemutusan adalah sama, dalam hal perkembangan morfologi makroskopis di alam. Perkembangan mikroskopis untuk pengamatan regenerasi organ internal masih sedikit laporannya.

Tujuan penelitian ini adalah mengetahui perubahan tubuh eksternal (panjang dan berat tubuh) dan organ internal (intestinalis, pohon respirasi dan gonad) teripang Gamat Batu S. horrens setelah terpotong (tranverse fission) dan keluar isi perut (eviserasi) sampai hari ke-28. Hasilnya penelitian ini melengkapi informasi kemampuan teripang untuk pertahanan diri (self-defense) dan pembentukan individu baru (new individu) dengan konsep reproduksi aseksual. Berkaitan dengan bidang teknologi budidaya ikan akan memperkuat dasar ilmu untuk pengembangan suatu teknologi tepat guna memproduksi induk teripang komersial (broodstocking) teripang bagi masyarakat pembudidaya teripang. Durasi waktu produksinya akan lebih cepat tanpa melalui siklus hidup yang panjang dari telur sampai ukuran dewasa, melainkan perbanyakan diri di tahap dewasa.

\section{METODE PENELITIAN}

Penelitian ini dilaksanakan selama 28 hari (9 September - 6 Oktober 2020). pemeliharaan teripang di wadah submarine trap berangka besi yang akan ditempatkan terbenam di bawah air. Hanya satu spesies teripang komersial, yaitu Gamat Batu S. horrens yang dipakai pada penelitian ini. Setelah aklimatisasi tiga hari, ada 30 individu yang dipakai dengan kisaran panjang tubuh yang diukur dari ujung mulut sampai ujung anus adalah 15,9 - 18,3 cm, rata-ratanya $17,0 \mathrm{~cm}$. Kisaran berat tubuh yang diperoleh adalah 680 - 952 gram dengan nilai rata-rata 813 gram.

Kegiatan penelitian in-situ ini terdiri atas dua tahapan kerja: (1) pemeliharaan teripang uji hasil pemotongan sampai menutup luka dan teripang uji hasil eviserasi; (2) Pengamatan perubahan bentuk dan ukuran organ internal (usus, pohon pernafasan dan kelenjar gonad).

Pada setiap teripang uji, setelah isi perut dikeluarkan, organ internalnya diidentifikasi (gonad, saluran intestinal atau pohon respirasi). Selanjutnya diletakkan di atas tisue kering selama 10 detik. Masingmasing spesimen dimasukan ke dalam botol sampel yang sudah diberi label. Pengukuran panjang tiap organ internal menggunakan kaliper. Untuk mengetahui batas organ internal yang baru beregenerasi akan dilakukan 
pewarnaan dengan perendaman selama 10 menit ke dalam larutan Methylin Blue. Warna yang cerah akan menunjukkan jaringan yang baru tumbuh, sedangkan yang agak gelap akan menunjukkan bagian jaringan yang lama (Hsieh, 2012). Untuk melihat hubungan perubahan panjang organ internal terhadap eksternal tubuh, maka setiap 7 hari perbandingan prosentase ukuran dan dipaparkan melalui histogram diagram batang dan tabel distribusi ukuran.

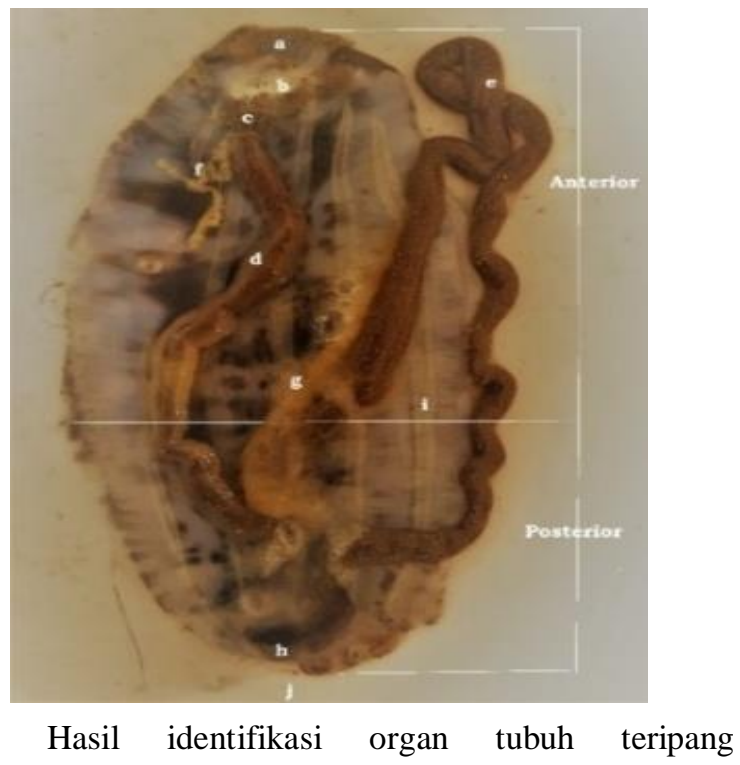

mendapatkan 9 bagian tubuh yaitu mulut, rongga mulut, kerongkongan, usus pertama, usus kedua, gonad, penampang mesentrial dan anus (Gambar 1).

Gambar 1. Penampang melintang organ internal teripang Gamat Batu (Stichhopus horrens) pada penelitian ini. Keterangan : a. mulut, b. rongga mulut, c. kerongkongan, d. usus pertama, e. usus kedua, f. gonad, g. anus, h. penampang mesenterial, i. anus

\section{HASIL DAN PEMBAHASAN}

\section{Kondisi tubuh eksternal setelah eviserasi dan dipotong}

Pada saat penebaran semua spesimen mengalami penyusutan baik panjang maupun berat tubuh. Penyusutan panjang untuk spesimen eviserasi disebabkan adanya bagian tubuh yang terbuang saat eviserasi dan dipotong melintang, yaitu isi perutnya : cairan tubuh, kotoran, sebagian organ internal (usus, pohon respirasi, dan gonad). Hasil analisa presentase penyusutan cukup besar jika dibandingkan dengan ukuran spesimen utuh. Sisa panjang tubuh spesimen eviserasi dari panjang awal pada tebar awal $\left(\mathrm{H}_{0}\right)$ sebesar $68 \%$, spesimen anterior $34 \%$ dan posterior $29 \%$ (Gambar 2). Pada pengamatan berikut setiap 7 hari sampai hari ke-28 $\left(\mathrm{H}_{28}\right)$ masih terus menyusut. Spesimen eviserasi tersisa $34 \%$, anterior $12 \%$ dan posterior $14 \%$. Begitu pula untuk perhitungan perubahan berat tubuh menurun sampai $49 \%$ untuk spesimen eviserasi, 30 dan $29 \%$ untuk spesimen anterior dan posterior pada hari pertama tebar $\left(\mathrm{H}_{0}\right)$. Penyusutannya masih berlangsung sampai hari ke-28 $\left(\mathrm{H}_{28}\right)$, yaitu $37 \%$ untuk eviserasi, $11 \%$ untuk anterior dan $9 \%$ untuk posterior. Informasi tambahan untuk penyusutan panjang tubuh teripang setelah dipotong baik kelompok anterior maupun posterior dikarenakan bagian tubuh yang terpotong mengalami penutupan luka di bagian yang luka.

Gambar 2. Persentase panjang dan berat tubuh teripang setelah eviserasi dan dipotong

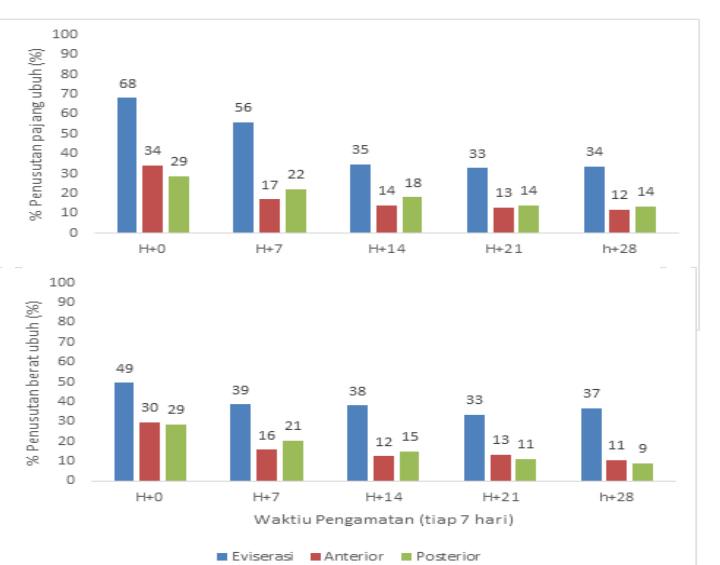

Hasil pengamatan sampai hari ke-28 belum ditemukan tonjolan pada bagian bekas luka (Gambar 3), sebagai tanda terbentuknya organ baru, berupa tentakel mulut pada individu posterior dan anus pada individu anterior. Pada saat dilakukan pembelahan dan

pengamatan organ internal (usus, pohon respirasi dan gonad) di kedua kelompok individu ini ternyata belum lengkap. Ketiga organ internal utama ini ditemukan 
lengkap pada kelompok eviserasi. Sedangkan pada kelompok anterior, kondisi saluran pencernaannya tersisa sebagian sampai batas usus pertama dan berpangkal di tenggorokan. Organ internal lainnya yaitu pohon respirasi hanya sebagian yang menempel bagian usus. Organ gonad ditemukan di sisi kiri dekat tenggorokan. Sedangkan pada kelompok posterior hanya sebagian usus serta pohon respirasi yang berpangkal pada bagian kloaka dan tidak ditemukan gonad.

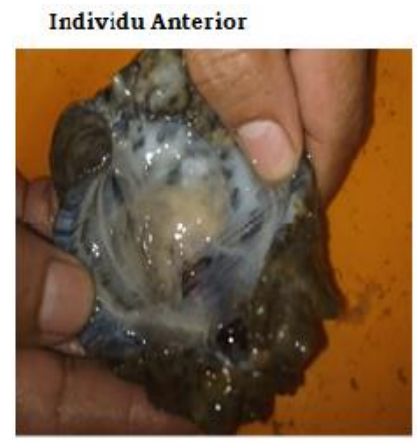

Individu Posterior

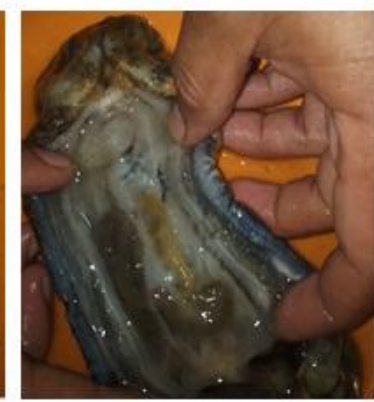

Gambar 3. Kondisi organ internal Teripang Gamat Batu S. horrens yang masih belum lengkap setelah 28 hari pemeliharaan

Perubahan ukuran organ internal setelah eviserasi dan dipotong

Organ intestinal yang diukur adalah dari batas tenggorokan sampai ujung terakhir usus ke arah kloaka. Hasilnya dalam bentuk presentase penyusutan panjang organ intestina spesimen eviserasi maupun dipotong untuk bagian posterior dan anterior terhadap ukuran pada spesimen yang tidak ada perlakuan (Gambar 4). Perbandingannnya menunjukan bahwa organ intestinal spesimen eviserasi pada tebar awal $\left(\mathrm{H}_{0}\right)$ yang tersisa sebesar $68 \%$, lebih tinggi dibandingkan individu anterior yang hanya $35 \%$ dan posterior sebesar $30 \%$. Pada pengamatan selanjutnya dengan selang waktu 7 hari sampai hari ke-28, organ intestinalis masih menyusut, (spesimen eviserasi tersisa : 10\%, anterior dan posterior masing-masiang 5\%). Sehingga memberikan arti bahwa pada 4 minggu pertama individu teripang gamat batu yang mengalami eviserasi dan dipotong belum ada regenerasi pada usus.

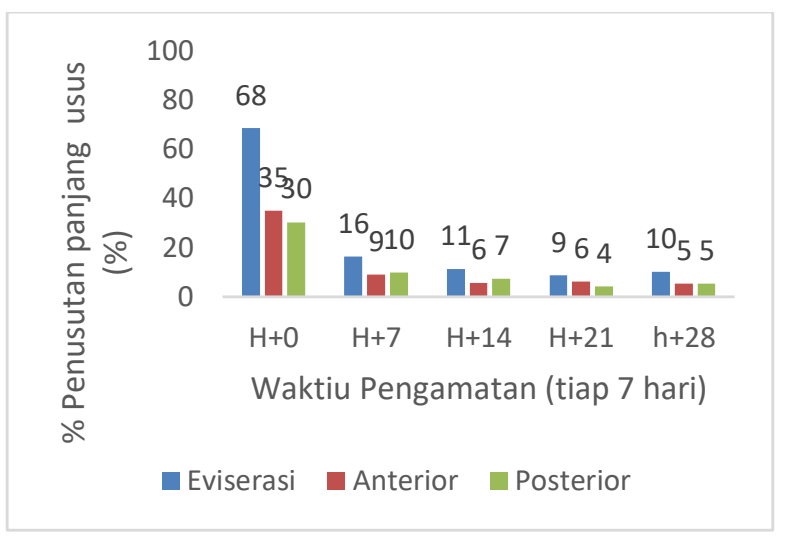

Gambar 4. Perubahan ukuran organ intestinal setelah eviserasi dan dipotong

Pohon Respirasi diukur dari batas pangkal kloaka sampai ujung terakhir ke arah anterior. Hasilnya dalam bentuk presentase penyusutan panjang dan berat saat eviserasi maupun dipotong (posterior dan anterior) terhadap ukuran spesimen yang tidak ada perlakuan : Gambar 5.

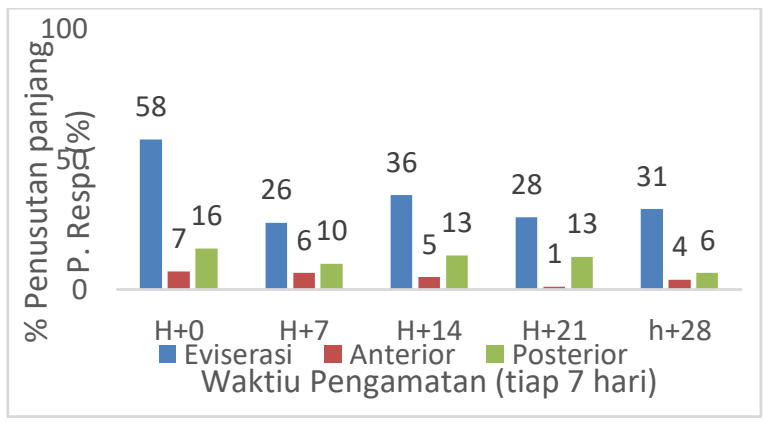

Gambar 5. Perubahan ukuran organ pohon respirasi setelah eviserasi dan dipotong

Perbandingannnya menunjukan bahwa pohon respirasi spesimen eviserasi pada tebar awal $\left(\mathrm{H}_{0}\right)$ yang tersisa sebesar 58\%, lebih tinggi dibandingkan individu anterior yang hanya $7 \%$ dan posterior sebesar $16 \%$. Pada pengamatan selanjutnya dengan selang waktu pengamatan tiap 7 hari sampai hari ke-28, pohon respirasi masih menyusut, (spesimen eviserasi tersisa : $31 \%$, anterior dan posterior masing-masing 4 dan 6\%). 
Sehingga memberikan arti bahwa pada 4 minggu pertama individu teripang gamat batu yang mengalami eviserasi dan dipotong belum melakukan regenerasi pada pohon respirasi.

Pengukuran panjang gonad dimulai dari pangkal yang terletak di bagian dekat mulut anterior, sampai bagian ujung yang menggantung di rongga tubuh. Keberadaan organ ini hanya ditemukan pada spesimen eviserasi dan anterior, sedangkan spesimen posterior tidak ada.

Perbandingan dengan specimen awal tanpa perlakuan mendapatkan bahwa ada penyusutan ukuran panjang gonad (\%) : Gambar 6. Pada saat tebar awal $\left(\mathrm{H}_{0}\right)$ spesimen eviserasi menyusut $65 \%$, sedangkan spesimen anterior lebih rendah, yaitu $41 \%$. Hal ini disebabkan ada bagian gonad yang terpotong saat dipotong. Pada pengamatan berikutnya, terjadi variasi nilai penyusutan baik spesimen eviserasi maupun anterior. Pada hari ke28 presentase penyusutan semakin rendah dengan capaian 39\% untuk kelompok eviserasi dan 30\% untuk kelompok anterior. Artinya belum ada pertambahan gonad pada kedua kelompok ini sampai akhir penelitian.

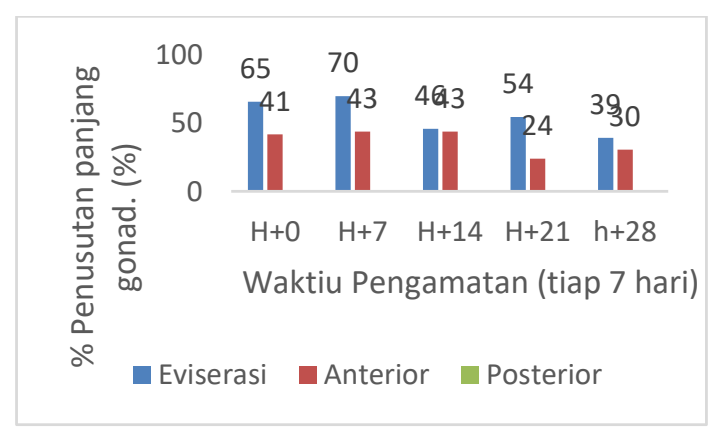

Gambar 6. Penyusutan ukuran organ gonad setelah eviserasi dipotong

Penelitian organ internal penting (intestinal, pohon respirasi dan gonad) Teripang Gamat Batu Stichopus horrens yang ber-eviserasi dan dipotong ternyata mengalami penyusutan ukuran (panjang dan berat) yang cukup besar sampai pada pemeliharaan 28 hari. Tidak ada spesimen yang bertambah ukurannya. Hubungan dengan penelitian sebelumnya (Langi dan Wuaten, 2019) yang mengulas bahwa teripang ini sampai pada hari ke-35 setelah pemutusan masih dalam kondisi pemulihan penutupan luka. Pada laporan tersebut tidak ada tahapan regenerasi yang ditandai dengan munculnya organ tubuh yang terputus. Tahapan regenerasi ini nanti akan muncul pada hari ke-150.

Menurut Dwiono (2009) pada tahap regenerasi ini Teripang sudah dapat memfungsikan organ pencernaan dan menyerap makanan. Hasil pengamatan pada kondisi organ intestinal, bahwa sampai hari ke-28, spesimen eviserasi pun tidak terdapat makanan pada bagian usus, artinya fungsi organ intestinal belum berfungsi.

Penyusutan panjang tubuh teripang yang dipotong baik individu anterior maupun posterior karena bagian tubuh yang terpotong mengalami penutupan luka sehingga ukuran tubuhnya akan lebih pendek. Menurut Dwiono (2009) pada kondisi ini teripang masuk pada tahap pemulihan luka, yaitu saat bagian tubuh yang terpotong menutup dan bekas lukanya mengerucut untuk melindungi bagian tubuh yang terbuka.

Pada bagian anterior masih dapat ditemukan organ-organ tubuh yang tidak hilang karena berpangkal di bagian tersebut, di antaranya mulut dan rongganya, gonad, dan potongan kecil usus. Sedangkan di bagian posterior masih terdapat anus dan kloaka, potongan usus dan pohon respirasi. Dolmatov (2014) melaporkan bahwa perbedaan kehadiran organ internal tiap bagian tubuh teripang yang mengalami pemutusan berhubungan dengan dengan lokasi organ-organ tersebut berada.

Dwiono (2009) mengkategorikan perubahan tubuh ini ke dalam tahap selanjutnya, yaitu regenerasi, yang dimulai dari munculnya tonjolan pada bagian bekas luka sampai menjelang terbentuknya tentakel atau anus baru. Selanjutnya petunjuk tambahan tahapan regenerasi ini pada semua teripang holothurian selain ada penonjolan organ, daerah permukaan dermis tubuh baru ini tidak berpigmen. Langi dan Wuaten (2019) 
melaporkan bahwa ciri-ciri bagian tubuh yang beregenerasi adalah dinding tubuhnya secara umum lebih tipis, berwarna lebih gelap dan lebih lunak pada spesimen Stichopus spp; lebih kecil pada spesimen $H$. atra dan lebih lunak, permukaan dermis agak memucat, tanpa pigmen pada spesimen $B$. marmorata dibandingkan bagian tubuh yang lama. Darsono (1999) melaporkan pula bahwa spesimen anterior dan posterior yang melakukan regenerasi dapat dikenali dengan mengamati bagian integumen yang mengalami regenerasi. Warnanya lebih muda dan berdiameter lebih kecil dibandingkan bagian tubuh lainnya. Bagian tubuh yang tersisa pada spesimen terpotong adalah yang melekat pada bagian anterior, yaitu pangkal tenggorokan, lambung dan sebagian usus. Bagian tubuhnya hilang. Sedangkan bagian posterior tidak sama sekali ditemukan saluran pencernaan. Hal ini menunjukan bahwa saluran pencernaan hanya melekat pada bagian terminal anterior dan bebas menggantung di rongga tubuh teripang. Jika terjadi eviserasi bagian tubuh yang dibuang adalah isi perut, yaitu kotoran, dan sebagian usus.

Nugroho $d k k$. (2012a) melaporkan bahwa pohon respirasi dipenuhi oleh connective tissue (jaringan ikat), dimana ketebalan jaringan ikat di bagian batang utama lebih tipis dapada cabang pohon respirasi. Dilaporkan bahwa dinding penyusun batang pohon respirasi Gamat Lumpur ( $S$. hermanni) lebih tebal dibandingkan dengan dinding pada cabang pohon respirasi. Penjelasan lanjutan Nugroho $d k k$. (2012b) bahwa pohon respirasi teripang baik Cerah Hitam, H. atra, P. graeffei, Gamat Hitam S. chloronotus dan Gamat lumpur (S. hermanni) terdiri atas dua jaringan : jaringan ikat yang lebih dominan dibandingkan jaringan otot.

Tipe pengeluaran yang terjadi pada Teripang Gamat Batu S. horrens terjadi melalui bagian posterior melalui saluran kloaka dan anus. Menurut Mashanov dan Arraras (2011) tipe pengeluaran dan pemutusan isi perut pada teripang biasa terjadi pada teripang kelompok Aspidochirota dan melibatkan semua usus mulai dari kerongkongan dan kloaka, dan juga dari yang melekat pada dinding tubuh. Bagian tubuh yang terpotong mulai dari usus, bersama dengan organ dalam terkait seperti pembuluh darah, gonad, dan salahsatu atau kedua pohon pernapasan, akan keluar di dinding kloaka. Tidak semua organ internalnya keluar. Hanya sebagian yang hilang atau dengan kata lain ukurannya akan memendek.

Menurut Purcell $d k k$. (2012) sistem reproduksi teripang terdiri dari gonad tunggal atau kelenjar kelamin. Navaro $d k k$. (2013) menyebutkan gonad tunggal tersebut dengan istilah tubulus. Tubulus ini melekat pada pangkal tubular yang terletak di bagian anterior dan membentuk percabangan. Gonad jantan dan betina dilapisi dinding tubulus yang tipis dan setiap tubulus akan berakhir pada saluran yang berujung pada gonopore. Baik jantan dan betina mengalami perkembangan gonad yang dapat dibedakan berdasarkan ukuran dan warna dari tubulus. Gonad terletak di bagian dorsal dan pada teripang kelompok Aspidochirotida terdiri 2 untaian tubulus untuk famili Stichopodidae.

\section{KESIMPULAN}

Teripang Gamat Batu Stichopus horrens yang bereviserasi dan dipotong melintang ternyata mengalami penyusutan ukuran (panjang dan berat) sampai pada pemeliharaan 28 hari. Tidak ada spesimen yang bertambah ukurannya. Jika terjadi eviserasi bagian tubuh yang dibuang adalah isi perut, yaitu kotoran, dan sebagian usus. Adanya penyusutan panjang tubuh teripang baik individu anterior maupun posterior karena bagian tubuh yang terpotong mengalami penutupan luka sehingga ukuran tubuhnya akan lebih pendek. Bagian tubuh yang tersisa pada spesimen ini adalah yang melekat pada bagian anterior, yaitu pangkal tenggorokan, lambung dan sebagian usus. Bagian tubuhnya hilang. Sedangkan bagian posterior tidak sama sekali ditemukan saluran pencernaan.

Kondisi organ intertenal (usus, pohon respirasi dan gonad) yang mengalami eviserasi maupun pemotongan mengalami penyusutan ukuran, baik saat tebar awal sampai hari ke-28. Bahkan pada kelompok 
posterior sama sekali belum ditemukan gonad. Sehingga memberikan arti bahwa pada 4 minggu pertama individu teripang Gamat Batu S. horrens belum melakukan regenerasi.

\section{DAFTAR RUJUKAN}

Conand, C. 1996. Asexual reproduction by fission in Holothuria atra : Variability Asexual Reproduction Regeneration Holothurian Strategy Indo-Pacific of some Parameters in Populations from the Tropical Indo-Pacific. Oceanologica Acta- vol 19 p 3-4.

Darsono, P. 1999. Reproduksi Aseksual pada Teripang, Oseana XXIV (2) : 1-11.

Dolmatov, I. Y. 2014. Asexual reproduction in Holothurians. Review Artcle. Hindawi Publishing Corporation. The Scientific World Journal. 13 pages.

Dwiono, S. A. P. 2009. Perbanyakan Holothuria atra (Echinodermata : Holothuridae) melalui Stimulasi Pembelahan. ISSN 0125 -9830. Oseanografi dan Limnologi di Indonesia 35 (1) : $47-56$.

Hermawan, Widianingsih, R. Hartati 2012. Stimulasi Reproduksi Aksesual Pada Stichopus horrens di Perairan Pulau Karimun jawa, Kabupaten Jepara. Journal of Marine Research.Volume 2, Nomor 1. 118 - 124 hal.

Hsieh V. 2012. Monitoring Organ Regeneration of Sea Cucumber Holothuria leucospilota After Evisceration. Department of Integrative Biology, University of California, Berkeley, California 94720 USA. 11 page.

Langi dan Wuaten, 2019. Regenerasi dan Pertumbuhan Tonjolan tubuh Teripang Stichopus hermannii, Holothuria atra dan Bohadschia marmorata dengan Dua Metode Pemutusan
Berbeda (Pengikatan dan Pemotongan) di Teluk Talengen-Sangihe, Indonesia. HKI Artikel, IP : 000158031.

Mashanov, V. S dan Garcia-Arraras, J. E. 2011. Gut Regeneration in Holothurians: A Snapshot of Recent Developments. Biol. Bull. 221: 93109.

Navaro, P. G. S. Garcia Sanz, J. M. Barrio and F. Tuya. 2013. Feeding and Movement Patterns of the Sea Cucumber Holothuria sanctori. Mar. Biol. 160 : 2595-2966. DOI 10.1007/s0027-0132286-5.

Nugroho D, R. Hartati, J. Suprijanto 2012a Stimulasi Fission Reproduksi Aksesual Teripang Holothuria atra dan Teripang Holothuria impatiens. Journal of Marine Research.Volume 2, Nomor 1. 161- 166.

Nugroho, G. B. S., R. Hartati dan K. Praseno. 2012 b. Hipokomparatif Organ Integumen, Intestinum, Pohon Respirasi pada Beberapa Jenis Teripang dari Perairan Karimunjawa. Jurnal of Marine research Volume 1. (1) : 67 74.

Pradina, 1996. Metoda Pengkajian Reproduksi Teripang (Holothuridae, Ekhinodermata). Lenowarta 1996. XIX : $13-22$.

Purcell,S,W.,Y. Samyn dan C. Conand 2012. Commercially Important Sea Cucumbers Of The World. FAO Species Catalogue For Fishery Purposes No. 6. Food and Agriculture Organization of the United Nations. Rome. 223 hal.

Saputra, A., E. Gunaisah, F. Ardianta, S. Ardianto. 2012. Pengembangbiakan aseksual Teripang Keling (Holothuria atra) di Kampung Manyaifun, Raja Ampat, Papua Barat. 71 - 75 hal. 